\title{
Soviet scientists' assessment of Strategic Defense Initiative
}

Washington

A COMPREHENSIVE, critical analysis of the US Strategic Defense Initiative (SDI) by three Soviet scientists was released last month in both English and Russian language editions. The book ${ }^{*}$ argues that the SDI programme will not only fail to work as planned, but will also destabilize the international balance of power and start a new arms race. At almost the same time, a group of US scientists released a report praising SDI, and urging acceleration of the proposed deployment timetable.

Academicians Yevgeni Velikhov and Roald Sagdeev, with Professor Andrei Kokoshin, have produced a set of original calculations relating to the feasibility and potential effectiveness of various SDI weapons systems. Although the book concentrates on the practical problems and limitations of the weapons being developed for a space-based ballistic missile defence, some receive guarded praise. Ground-based excimer lasers are considered "promising" components of a space-based ballistic missile defence. Particle-beam systems "possess a certain potential as weapons against kinetic energy projectiles at relatively short ranges". But, the authors conclude that the problems of developing and deploying such systems are "far from being solved".

The book presents several alternatives for neutralizing a space-based ballistic missile defence. Fast-boost missiles, lower ballistic trajectories, concealment, multiple fake warheads and altering brightness and configuration of exhaust missile plume all confound SDI, and are relatively cheap to implement. Active weapons for destroying space-based battle stations include 'space mines' and 'space shrapnel'. Ground-based lasers would be effective in defeating space-based weapons.

Of greater concern is the potential use of SDI as an offensive system. Particle beams might be used as weapons against airborne and ground-based targets. If it became possible for the United States to destroy planes over Soviet territory, "this would change the strategic landscape beyond recognition". A likely outcome of SDI development will be a new round of the arms race in space. Defending against such a offensive capability of SDI would be more expensive but still possible, the authors argue.

Other technical problems predicted for SDI include reliability, adequate sensor capabilities and software development. With so complex a system, the chance of accidental activation becomes significant, the authors argue. Detecting and disting-

"Weaponry in space: the dilemma of security; Mir Publishers, Moscow, 1986 uishing a hostile launch will be a problem.

There are also legal and political problems. The authors see development of SDI as a clear violation of the AntiBallistic Missile Treaty of 1972 . SDI will also be ineffective for protecting Europe, and will destabilize a world where strategic weapons are now in relative balance.

The Pentagon is unimpressed by these criticisms of SDI. A spokesperson stated that all countermeasures suggested in the study have been taken into account by SDI planners. The Defense Department argues that Soviet spending on strategic defences make claims that such a system would not work irrational. If SDI will not work, how can it be destabilizing?

In a report prepared for the George $\mathrm{C}$. Marshall Institute - John Gardner, Edward Gerry, Robert Jastrow, William
Nierenberg and Frederick Seitz - argue that a defensive system with 90 per cent effectiveness could be deployed by 1994 costing only $\$ 121,000$ million. They envisage using kinetic energy weapons rather than lasers or particle beams to destroy missiles in boost phase and late-midcourse phase. Terminal-phase defence would come from heat-seeking missiles. The authors say 42,000 Soviet rockets would be needed to destroy 1,000 US targets, which "forecloses the possibility of a nuclear first strike on the United States".

On the other hand, the Soviet authors argue that if President Reagan is truly anxious to render nuclear weapons 'impotent and obsolete', an alternative to SDI would be to do away with them. It will take a miracle, they say, to provide solutions to multiple problems of a comprehensive ballistic missile defence. Lest US SDI proponents count on one, they warn that "it is equally likely that the miracle' will be used by the other side with the same or even greater effects". Joseph Palca

\section{Japanese experimental nuclear reactor decommissioned}

\section{Tokyo}

As Japan's nuclear power industry grows by leaps and bounds, the problem of how to deal with reluctant commercial nuclear reactors looms on the horizon. The dismantling of Japan's first experimental nuclear power reactor began last month.

The JPDR boiling-water reactor at the Atomic Energy Research Institute in Tokai village, north of Tokyo, produced Japan's first nuclear power in 1963 . Now the $12,500-\mathrm{kW}$ experimental reactor, which ceased operations in 1976, is dwarfed by Japan's 32 commercial reactors, several of which are in the 1 million kW class. By 2030, Japan should have more than 120 nuclear reactors supplying over half of the country's electricity (see Nature 322, 388; 1986). But by then many of the present reactors will need to be dismantled.

Despite JPDR's small size, it will take five years, Y10,000 million ( $£ 43$ million) and the latest robot technology to take the reactor apart. That cost does not include the Y10,000 million Japan has already spent since 1981 on developing techniques for decommissioning.

Dismantling began by cutting away the top of the reactor's pressure vessel. Over the next two years, the internal parts of the reactor, excluding fuel and control rods, will be removed by robot arms and chopped up into small pieces for storage. Next, a demolition squad of robot 'mice' equipped with explosives will blast the pipes connected to the pressure vessel. In 1990-91, the reactor shield and surrounding buildings will be demolished using, among other techniques, a microwave gun to destroy the concrete shield walls. During the operation about 4,000 tonnes of radioactive waste with an activity of 4,500 curies will be produced which will be stored temporarily in drums at the Takai site.

Under agreements signed last month, information on the decommisioning of JPDR will be supplied to the UK Atomic Energy Authority at Sellafield and Canada's Atomic Energy of Canada Ltd. The agreement with the United Kingdom includes information exchange on decommissioning techniques, waste management and a data collection system, that with Canada covers application and development of a computerized code system for management of reactor decommissioning.

The JPDR operation, however, is not the only way to decommission a reactor. A much simpler approach was recently used to dispose of the $100,000 \mathrm{~kW}$ JRR-3 reactor, also at the Tokai Institute, which had been used as a neutron beam source. The 2,250-tonne reactor was hoisted up on jacks, rolled $34 \mathrm{~m}$ across the laboratory floor and lowered into a hole $15 \mathrm{~m}$ deep, where it will be entombed in concrete for the next hundred years. But such a technique cannot be applied to Japan's huge commercial reactors which, like JPDR, will be taken apart piece by piece.

The first commercial nuclear plant expected to expire in Japan is a gas-cooled reactor imported from Britain, which came on like in 1966. Its decommissioning, a mammoth task compared with dismantling JPDR, should begin around the turn of the century. 